\title{
Editorial
}

\section{COMBINED TREATMENT FOR LEPROMATOUS LEPROSY}

The enormous problems posed by the widespread emergence of dapsoneresistant strains of Mycobacterium leprae among lepromatous patients who have been treated with dapsone monotherapy, and among those whom they may subsequently infect, are now widely recognised and it is generally agreed that the only potentially successful method of preventing the situation from becoming yet more serious is to initiate the treatment of all new lepromatous patients with combinations of antileprosy drugs. ${ }^{1-5}$ This paper reviews the experimental and pharmacological studies that have been carried out to assess the potencies of both established and more recently investigated antileprosy drugs, and proposes a combined treatment regimen which should not only be highly effective but also capable of widespread use under field conditions.

The relative activities of antileprosy drugs can be assessed in the mouse foot-pad system by feeding graded doses of compounds to infected mice and determining the minimal effective dose capable of preventing the multiplication of leprosy bacilli. ${ }^{6}$ Measurement of the serum or tissue concentrations of the drug in mice fed with this dose provides a very approximate estimate of the minimal inhibitory concentration (MIC) of the compound against M. leprae. ${ }^{7,8}$ The most active drugs are dapsone which prevented leprosy bacilli multiplying at a concentration of only $0.003 \mu \mathrm{g} / \mathrm{ml} .^{9,10}$ and the thioamides, ethionamide and prothionamide with MICs of about $0.05 \mu \mathrm{g} / \mathrm{ml} .{ }^{11}$ The minimal inhibitory concentration of clofazimine against $M$. leprae could not be assessed because of uneven tissue accumulation.

Whether the activity of an antileprosy drug is purely bacteriostatic or not can be established by the kinetic method devised by Shepard ${ }^{12}$ and if this test indicates that the drug may possess bactericidal activity, the degree of bacterial killing can be quantitated by the proportional bactericidal test method recently described by Colston and his colleagues. ${ }^{13}$ Using this method they showed that at dietary doses giving blood levels in mice similar to those known to be well tolerated in man, rifampicin was by far the most powerful bactericidal drug, killing $99.99 \%$ or more of the bacilli, while ethionamide and prothionamide had virtually identical antileprosy activities and killed $98-99 \%$ 
of the bacilli. By contrast dapsone was only weakly bactericidal killing about $75 \%$ of the organisms and thiacetazone was without significant bactericidal activity. These findings confirm those obtained using the kinetic method $^{3,6,11,14-18}$

It is possible to compare the likely potencies of the antileprosy drugs in clinical treatment by considering their experimentally-determined MICs against $M$. leprae, their bactericidal activities in the mouse foot-pad and the results of studies on their pharmacology in man. The most important parameters are 1) the ratio of peak serum or tissue levels achieved with well tolerated doses in man to their MIC against M. leprae, which is an approximate indication of the therapeutic margin of the drug, 2) for bactericidal drugs, the likely rapidity and extent of bacterial killing at the concentrations attainable in man, and 3) for purely bacteriostatic drugs, the duration after a single dose during which body levels exceed the MIC, since this gives an approximate indication of the regularity with which successive doses need to be taken if treatment failure caused by multiplication of leprosy bacilli between doses is to be prevented $^{7} 8,11,19,20$

Experimental and pharmacological data that enable approximate comparisons to be made of the likely relative potency of different drugs for the treatment of lepromatous patients are summarised in Table 1. Such considerations

Table 1. Minimal inhibitory concentrations against $M$. leprae (MICs), peak serum concentrations, durations of coverage and bactericidal activities of antileprosy drugs

\begin{tabular}{llcccc}
\hline Drug & $\begin{array}{c}\text { MIC } \\
(\mu \mathrm{g} / \mathrm{ml})\end{array}$ & $\begin{array}{c}\text { Human } \\
\text { dosage } \\
(\mathrm{mg})\end{array}$ & $\begin{array}{c}\text { Ratio peak* } \\
\text { serum conc } \\
\text { to MIC }\end{array}$ & $\begin{array}{c}\text { Duration } \\
\text { which serum } \\
\text { concs exceed } \\
\text { MIC (days) }\end{array}$ & $\begin{array}{c}\text { Bactericidal } \\
\text { activity }\end{array}$ \\
\hline Rifampicin & 0.3 & 600 & 30 & 1 & +++ \\
Dapsone & 0.003 & 100 & 500 & 10 & + \\
Ethionamide/Prothionamide & 0.05 & 375 & 45 & 1 & $(++) \S$ \\
Acedapsonell & 0.003 & 225 & 15 & 200 & - \\
Thiacetazone & 0.2 & 150 & 8 & 2 & - \\
\hline
\end{tabular}

${ }^{*}$ Ratio of peak serum concentration in man after a single dose to MIC determined in the mouse.

† Serum concentrations in man after a single dose.

$\ddagger$ Purely bacteriostatic $(-)$; relative degrees of bactericidal activity $(+,++,+++)$.

$\S$ Not yet assessed clinically.

IAcedapsone is active against $M$. leprae by conversion to dapsone; the figures for MIC and peak serum concentration refer to the values for dapsone.

explain why rifampicin and dapsone are the two most powerful antileprosy drugs in clinical use. Thus doses of $600 \mathrm{mg}$ rif ampicin give peak serum levels that are about 30 times its MIC against $M$. leprae and sufficient to result in rapid and substantial bactericidal activity. Although the peak levels attained 
after giving $100 \mathrm{mg}$ doses of dapsone only result in weak bactericidal activity, they exceed MIC by about 500 -fold. Such a high therapeutic margin is quite exceptional and of great importance since these levels will also inhibit the multiplication of mutants of $M$. leprae with low or even moderate degrees of dapsone resistance. Furthermore such a dose should main tain inhibitory levels of dapsone against fully sensitive leprosy bacilli for about 10 days.

Ethionamide and prothionamide would be expected to show bactericidal activity intermediate between that displayed by rifampicin and dapsone, but this has yet to be established in a controlled clinical trial. Acedapsone is a formulation of diacetyl-dapsone for intramuscular injections which releases dapsone into the body so slowly that a single $225 \mathrm{mg}$ dose maintains inhibitory dapsone levels for about 200 days. ${ }^{21}$ However such levels would only be expected to inhibit the multiplication of fully dapsone-sensitive $M$. leprae and are probably purely bacteriostatic. ${ }^{22,}{ }^{23}$ Clinical and bacteriological evidence suggests that the potency of clofazimine is similar to that of acedapsone. ${ }^{24}$ The weakest drug, according to these parameters is thiacetazone. Thus after giving $150 \mathrm{mg}$ of the drug, the highest well-tolerated daily dose, peak serum levels only exceed its MIC against $M$. leprae by about 8 -fold, and inhibitory concentrations are only maintained for about 2 days. $^{3}$ Furthermore, since thiacetazone is primarily a bacteriostatic drug, ${ }^{3,13}$ it is likely that any serious irregularities in daily self-administration would result in leprosy bacilli recommencing to multiply.

Untreated lepromatous patients may harbour as many as $10^{11}$ leprosy bacilli of which about $10 \%$ are likely to be viable. ${ }^{7}$ The bactericidal activity of rifampicin is so rapidly manifested that after as little as a week's treatment with daily doses of $600 \mathrm{mg}$ rifampicin, over $99 \%$ of the viable bacilli are killed and inocula become non-infectious for mice. ${ }^{17,25,26}$ Thereafter small numbers of viable drug-sensitive "persisters" 27 appear to survive further killing by rifampicin. ${ }^{26}$ There may also be some rifampicin-resistant mutants that would eventually lead to patients relapsing if rifampicin monotherapy were continued indefinitely, ${ }^{28}$ but their multiplication would be prevented by giving a second drug such as dapsone in combination with rif ampicin.

When lepromatous patients are treated with supervised daily doses of $50-100 \mathrm{mg}$ dapsone, bacterial killing of the drug-sensitive bacilli takes place much more slowly and inocula only become non-infective for mice after about 3 months. ${ }^{29}$ Such doses of dapsone would be expected to lead a significant reduction in the numbers of mutants with low degrees of dapsone resistance, but to have very little effect on mutants with medium degrees of dapsone resistance. ${ }^{20}$ The elimination of drug-sensitive bacilli achieved by giving 3 -monthly injections of $225 \mathrm{mg}$ acedapsone, which are equivalent to daily dosage with about $2 \mathrm{mg}$ dapsone, is considerably slower. ${ }^{22}$ Furthermore such treatment would probably not result in the elimination of mutants with low degrees of dapsone resistance, and so could hasten the selection of 
dapsone-resistant mutants and the eventual relapse of the patient with dapsoneresistant leprosy. ${ }^{20}$ Irregular ingestion of larger doses of dapsone would be expected to have similar consequences. The multiplication of all these dapsoneresistant mutants would however be prevented by a second antileprosy drug.

The irregularity with which many out-patients attend treatment clinics is a problem that is widely recognised. However recent studies have indicated that even patients who attend regularly to collect their antileprosy treatment may often be grossly irregular in the way in which they actually ingest their dapsone tablets. Thus studies from both Africa and $\mathrm{Asia}^{30-34}$ indicate that as many as $30 \%$ of the out-patients attending treatment clinics actually ingested less than $25 \%$ of their prescribed treatment. These findings therefore emphasize the importance of trying to supervise the taking of antileprosy drugs where this is at all possible.

A possible combined regimen for the treatment of bacteriologically positive lepromatous leprosy patients is set out in Table 2. This treatment scheme

Table 2. Suggested treatment scheme for lepromatous patients using rifampicin, acedapsone and dapsone

\begin{tabular}{|c|c|}
\hline Drug dosage & Likely Outcome \\
\hline $\begin{array}{c}\text { Initial } 1-2 \text { weeks period } \\
\text { (supervised) }\end{array}$ & More than $99 \%$ M. leprae killed \\
\hline Rif ampicin $600 \mathrm{mg}$ daily & Sensitive \\
\hline & Low DDS-resistant \\
\hline & Medium-high DDS-resistant (? all) \\
\hline \multicolumn{2}{|l|}{$\begin{array}{l}\text { Dapsone } 100 \mathrm{mg} \text { daily } \\
\text { Acedapsone first } 225 \mathrm{mg} \text { dose }\end{array}$} \\
\hline Continuation treatment & Growth of M. leprae prevented \\
\hline $\begin{array}{l}\text { Rifampicin } 600 \mathrm{mg} \text { once-monthly } \\
\text { (supervised) }\end{array}$ & DDS-resistant \\
\hline Acedapsone $225 \mathrm{mg} 3$-monthly & Sensitive \\
\hline (supervised) & Rifampicin-resistant \\
\hline $\begin{array}{l}\text { Dapsone } 100 \mathrm{mg} \text { daily } \\
\text { (unsupervised) }\end{array}$ & Low DDS-resistant \\
\hline
\end{tabular}

employs the three most potent and well-tolerated antileprosy drugs, rifampicin, dapsone and acedapsone, in a manner permitting the maximal amount of supervision under field conditions. In this scheme patients would initially be treated as in-patients for a period of $1-2$ weeks in order for them to receive a course of fully supervised daily treatment with $600 \mathrm{mg}$ rifampicin together with $100 \mathrm{mg}$ dapsone and their first intramuscular injection of $225 \mathrm{mg}$ acedapsone. The rifampicin component of this treatment should ensure that over $99 \%$ of the patients drug-sensitive leprosy bacilli would be killed, together with a similar proportion of mutants with all degrees of dapsone resistance. Furthermore, since it is likely that the numbers of mutants initially present with higher 
degrees of dapsone resistance would be small, one might hope that they could be eliminated by this course of rifampicin treatment. ${ }^{20}$ By initiating treatment in this way one should therefore be able to obtain results that would be superior to the best that could ever be hoped for after at least 3 months outpatient treatment with dapsone; i.e. among patients that were infected with fully dapsone-sensitive organisms and who swallowed all their prescribed dapsone tablets.

Treatment would then be continued on an out-patient basis with a single dose of $600 \mathrm{mg}$ rifampicin being swallowed under supervision when the patients came once a month to collect their supply of $100 \mathrm{mg}$ dapsone tablets for selfadministration. Once every three months the patients would also be given an intramuscular injection of $225 \mathrm{mg}$ acedapsone.

The injections of acedapsone should ensure that the growth is prevented of all the drug-sensitive and rifampicin-resistant $M$. leprae that survived the initial period of daily supervised rifampicin treatment, while the once-monthly supervised rifampicir doses should prevent the multiplication of any surviving dapsone-resistant mutants. Finally patients would be encouraged to take their self-administered dapsone tablets as regularly as possible in order to provide additional protection against the possibility of dapsone-resistant mutants growing between the monthly supervised rifampicin doses. Since it is at present impossible to estimate how long combined treatment should be given before patients can be safely continued with just acedapsone and dapsone, one must recommend continuing treatment with the once-monthly supervised rifampicin dose for as long as possible.

Such a regimen should be highly effective in preventing patients from eventually relapsing with dapsone-resistant leprosy, should rapidly render them non-infective for their contacts, should be excellently tolerated and has a high level of supervisability. Furthermore, drug costs would be relatively moderate, of the order of about 30 U.S. dollars per patient per year. Additionally, if finances permitted, the regimen might be strengthened by giving each patient a second $600 \mathrm{mg}$ dose of rifampicin each month to be swallowed on the day after the visit to the clinic. ${ }^{35}$

The studies reviewed above indicate that the most promising alternative to once-monthly rifampicin to combine with acedapsone and dapsone in order to prevent the emergence of dapsone resistance would be daily dosage with $50 \mathrm{mg}$ clofazimine or with $375 \mathrm{mg}$ ethionamide or prothionamide. However these drugs are inherently less potent than rifampicin and are likely to be less well tolerated than single monthly doses of $600 \mathrm{mg}$ rifampicin. Furthermore, treatment of out-patients with these drugs would be impossible to supervise so that there would be a considerable risk of such regimens breaking down because of poor patient compliance. Also, at current prices, daily treatment with these doses of ethionamide or prothionamide would be 3-4 times more costly than with monthly doses of $600 \mathrm{mg}$ rifampicin. For the treatment of patients who 
had relapsed with proven dapsone resistance, practical regimens might consist of a combination of once-monthly supervised rifampicin with unsupervised daily clofazimine for dark-skinned patients, or with daily ethionamide or prothionamide for those who would find the skin discoloration caused by clofazimine unacceptable.

G.A. ELLARD

\section{References}

1 Pearson JMH, Haile GS, Rees RJW. Primary dapsone-resistant leprosy. Lepr Rev, 1977, 48, 129-32.

2 WHO Expert Committee on Leprosy. Fifth Report. WHO Technical Report Series, No. 607. Geneva: World Health Organisation, 1977.

${ }^{3}$ Colston MJ, Hilson GRF, Ellard GA, Gammon PT, Rees RJW. The activity of thiacetazone, thiambutosine, thiocarlide and sulphamethoxypyridazine against Mycobacterium leprae in mice. Lepr Rev, 1978, 49, 101-13.

4 Rees RJW. Combined therapy in principle and practice for the control of dapsone resistance. Lepr Rev, 1978, 49, 97-100.

5 Pearson JMH, Haile GS, Barnetson RStC, Rees RJW. Dapsone-resistant leprosy in Ethiopia. Lepr Rev, 1979, 50, 183-99.

6 Shepard CC. A survey of the drugs with activity against M. leprae in mice. Int J Lepr, $1971,39,340-8$.

7 Committee on Experimental Chemotherapy. Experimental chemotherapy of leprosy. Bull Wld Hlth Org, 1976, 53, 425-33.

8 Rees RJW, Ellard GA, Ambrose EJ, Colston MJ, Levy L, Morrison NE, Pattyn SR, Pearson JMH, Peters JH, Shepard CC. Report of the workshop on experimental chemotherapy, Eleventh International Leprosy Congress. Int J Lepr, 1979, 47, (Suppl.), 297-303.

9 Peters JH, Gordon GR, Murray JF, Fieldsteel AH, Levy L. Minimal inhibitory concentration of dapsone for Mycobacterium leprae in rats. Antimicrob Agents Chemother $1975,8,551-7$.

10 Levy L, Peters JH. Susceptibility of Mycobacterium leprae to dapsone as a determinant of patient response to acedapsone. Antimicrob Agents Chemother 1976, 9, 102-12.

11 Colston MJ, Ellard GA, Gammon PT. Drugs for combined therapy: Experimental studies on the antileprosy activity of ethionamide and prothionamide, and a general review. Lepr Rev, 1978, 49, 115-26.

12 Shepard CC. A kinetic method for the study of activity of drugs against Mycobacterium leprae in mice. Int J Lepr, 1967, 35, 429-35.

13 Colston MJ, Hilson GRF, Banerjee DJ. The "proportional bactericidal test": A method for assessing bactericidal activity of drugs against Mycobacterium leprae in mice. Lepr $\operatorname{Rev} 1978,49,7-15$.

14 Shepard CC. Further experience with the kinetic method for the study of drugs against Mycobacterium leprae in mice. Activities of DDS, DFD, ethionamide, capriomycin and PAM 1392. Int J Lepr, 1969, 37, 389-397.

15 Holmes IB, Hilson GRF. The effect of rifampicin and dapsone on experimental Mycobacterium leprae infections: minimum inhibitory concentrations and bactericidal action. J Med Microbiol, 1972, 251-61.

16 Shepard CC. Combinations of drugs against Mycobacterium leprae studied in mice. Int J Lepr, 1972, 40, 33-9. 
17 Shepard CC, Levy L, Fasal P. Rapid bactericidal effect of rifampin on Mycohacterium leprae. Amer J Trop IIyg, 1972, 21, 446-9.

18 Shepard CC. Combinations involving dapsone, rifampin, clofazimine, and ethionamide in the treatment of $M$. leprae infections in mice. Int J Lepr, 1976, 44, 135-9.

19 Ellard GA. Recent advances in the chemotherapy of leprosy. Lepr Rev, 1974, 45, 31-40.

20 Ellard GA. Pharmacological aspects of the chemotherapy of leprosy. Lepr Rev, 1975, 46 (Suppl.), 41-51.

${ }^{21}$ Peters JH, Murray JF, Gordon GR, Levy L, Russell DA, Scott GC, Vincin DR, Shepard CC. Acedapsone treatment of leprosy patients: response versus drug disposition. Amer J Trop Med Hyg 1977, 26, 127-36.

Shepard CC, Levy L, Fasal P. The death rate of Mycobacterium leprae during treatment of leprosy with acedapsone (DADDS). Amer J Trop Med Hyg 1972, 21, 440-5.

${ }^{23}$ Fieldsteel AH, Levy L. Dapsone chemotherapy of Mycohacterium leprae infection of the neonatally thymectomized Lewis rat. A mer J Trop Med Hyg, 1976, 25, 854-9.

Levy L, Shepard CC, Fasal P. Clofazimine therapy of lepromatous leprosy caused by dapsone-resistant Mycobacterium leprae. Amer J Trop Med Hyg, 1972, 21, 315-21.

Shepard CC, Levy L, Fasal P. Further experience with the rapid bactericidal effect of rifampin on Mycobacterium leprae. Amer J Trop Med Hyg, 1974, 23, 1120-4.

${ }^{26}$ Waters MFR, Rees RJW, Pearson JMH, Laing ABG, Helmy HS, Gelber RH. Rifampicin for lepromatous leprosy: nine years' experience. Brit Med J, 1978, 1, 133-6.

27 Waters MFR, Rees RJW, McDougall AC, Weddell AGM. Ten years of dapsone in lepromatous leprosy: clinical, bacteriological and histological assessment and finding of viable leprosy bacilli. Lepr Rev, 1974, 45, 288-98.

Jacobsen RR, Hastings RC. Rifampicin-resistant leprosy. Lancet, 1976, 2, 1304-5.

Shepard CC, Levy L, Fasal P. The death of Mycobacterium leprae during treatment with 4,4'-diaminodiphen ylsulfone (DDS). A mer J Trop Med Hyg, 1968, 17, 769-75.

Ellard GA, Gammon PT, Harris JM. The application of urine tests to monitor the regularity of dapsone self-administration. Lepr Rev, 1974, 45, 224-34.

Low SJM, Pearson JMH. Do leprosy patients take dapsone regularly? Lepr Rev, 1974, 45, $218-23$.

32 Huikeshoven HCJ, Honhoff C, Van Eys GJJM, Anten JGF, Mayer JMA, Van Helden HPT. Weekly self-medication of leprosy patients monitored by DDS/creatinine ratios. Lepr Rev, 1976, 47, 201-9.

Balakrishnan S. Monitoring self administration of dapsone by patients. Lepr India, 1977, 49, 364-71.

${ }^{34}$ Hagan KJ, Smith SE, Gyi KM, Lwin MM, Myiang YY, Oo KM, Shwe T, Tin KM, Than $\mathrm{KN}$, Hla T, Kywe WW. The reliability of self-administration of dapsone by leprosy patients in Burma. Lepr Rev, 1979, 50, 201-11.

35 Rees RJW. Rifampicin: the investigation of a bactericidal drug. Lepr Rev, 1975, 46 (Suppl.), 121-4. 